\title{
Sulfate-reducing bacteria in temporarily oxic sediments with bivalves
}

\author{
I. Bussmann ${ }^{1}$, W. Reichardt ${ }^{2}$ \\ ${ }^{1}$ GEOMAR, Forschungszentrum für marine Geowissenschaften, Wischhofstr. 1-3, W-2300 Kiel 14, Germany \\ ${ }^{2}$ Institut für Meereskunde, Düsternbrooker Weg 20, W-2300 Kiel, Germany
}

\begin{abstract}
Under seasonally fluctuating redox conditions in sediment of Kiel Bay (eastern Baltic Sea), viable counts (MPN) of sulfate-reducing bacteria (SRB) ranged between $4 \times 10^{2}$ and $7 \times 10^{4} \mathrm{~cm}^{-3}$ These MPN appeared fairly independent of ambient redox potentials and followed peaks of phytoplankton productivity in the water column with a time lag of 2 to $3 \mathrm{wk}$. The relative proportions of SRB using acetate, lactate or succinate as their electron donors fluctuated widely. Shells of the clam Arctica islandica, which can survive anoxia, were, even in oxic sediments, colonized by epizoic SRB. Significant differences between the abundance of epizoic SRB and SRB from ambient sediment were not detected. In terms of enrichment kinetics, however, epizoic SRB, and particularly those depending on succinate as electron donor, showed quicker responses. It is hypothesized that SRB associated with benthic infauna represent the biogeochemically more reactive group.
\end{abstract}

\section{INTRODUCTION}

Anoxic surface sediments, which cover not more than $10 \%$ of the sea floor, are mainly bound to the shallow, most productive areas of the world ocean (Henrichs \& Reeburgh 1987). In these, decomposition of organic matter is channeled through fermentative, methanogenic, or respiratory pathways involving reduced nitrate, ferric iron, manganese or sulfate as terminal electron acceptors. Dissimilatory sulfate reduction accounts for the bulk of carbon mineralization in marine anoxic sediments (Crill \& Martens 1987). Up to $50 \%$ of the respiratory electron flow in coastal anoxic sediments is mediated by sulfate reduction (Jørgensen \& Sørensen 1985).

Rates of sulfate reduction depend on the available concentrations of electron donors and acceptors as well as on population densities of the obligately anaerobic sulfate-reducing bacteria (SRB) as the catalytic agents. Earlier attempts to assess population densities of SRB in the marine environment were based on enrichment media containing lactate as sole carbon source for SRB of the Desulfovibrio desulfuricans type (e.g. Jørgensen 1978, Gunnarsson \& Rönnow 1982, Hines \& Buck 1982). The discovery of further metabolic types of SRB with different substrate requirements (Widdel 1980) made it necessary to extend the range of enrichment substrates in order to update estimates for the standing crop of cultivable populations of SRB (Laanbroek \& Pfennig 1981, Battersby et al. 1985).

Many of the potential niches for SRB in marine sediments are only seasonally anoxic depending on bulk input of organic matter via sedimentation of phytoplankton. Thus it appeared desirable to know how SRB populations are affected by seasonal changes of temperature, nutrient input and oxygen depletion (Graf et al. 1982).

According to Hines et al. (1982), sulfate reduction rates can be enhanced in bioturbated sediments. Yet the role of benthic macrofauna as a potential stimulant of sulfate reduction and SRB is far from clear. Lowchain fatty acids as preferred growth substrates for SRB are produced as fermentation products during anoxic survival of clams (Kluytmans et al. 1975). Growth of epizoic SRB among other heterotrophs on clams has been noted only once (Bussmann \& Reichardt 1990). In the temporarily anoxic sediments of Kiel Bay, survival of both starvation and exposure to oxygen should become a crucial steering factor for the distribution of obligately anaerobic heterotrophs such as SRB. To search for clues to the influence of predominant benthic macroinvertebrates on the standing crop of SRB, the latter were enumerated in both sediment samples and scrapings from shell surfaces of the 
clam Arctica islandica. Distribution patterns of SRB were compared with fluctuations of pertinent environmental variables in Kiel Bay sediment. Furthermore, it was attempted to describe the diversity of marine SRB with respect to substrate preferences and enrichment kinetics.

\section{MATERIALS AND METHODS}

Sediment cores and bivalves (Arctica islandica) from Kiel Bay (western Baltic $54^{\circ} 36^{\prime} \mathrm{N}, 10^{\circ} 27^{\prime} \mathrm{E}$ ) at $18 \mathrm{~m}$ water depth were obtained from March to December 1989 using a Reineck box core sampler aboard RV 'Littorina'. Redox potentials were recorded in sediment profiles down to a depth of $10 \mathrm{~cm}$ using a $\mathrm{Pt}-\mathrm{Ag} / \mathrm{AgCl}$ electrode.

In the laboratory, single specimens of Arctica islandica were incubated in gas-tight, dark PVC tubes $(22 \times 10 \mathrm{~cm})$ with sediment from the sampling station, leaving the top $4 \mathrm{~cm}$ for a sea water overlay. These tubes were incubated in a water bath at $10^{\circ} \mathrm{C}$ and were gassed with $\mathrm{N}_{2} / \mathrm{CO}_{2}(90: 10)$ for $2 \mathrm{~min}$ to create anaerobic conditions. To exclude other macrofauna, sediment was sieved through a $1 \mathrm{~mm}$ sieve. Experiments were run in triplicate with and without clams.

Succinate concentrations in pore water were determined after centrifugation of sediment samples at $14000 \times g(20 \mathrm{~min})$ under $\mathrm{N}_{2} / \mathrm{CO}_{2}$. An enzymatic assay based on the production of NADH in a coupled reaction of succinate thiokinase and pyruvate kinase was employed according to Michal et al. (1976) using reagents from Boehringer.

MPN (most probable number) determinations of SRB were made using (1) ambient sediment subsamples from cores with Arctica islandica from below $5 \mathrm{~cm}$ depth and at a distance of at least $10 \mathrm{~cm}$ from the clam, and (2) epizoic samples from the periostracum of this clam. In the latter case, material scraped from up to 10 individuals had to be combined. Using cut off $5 \mathrm{ml}$ syringes, $2.5 \mathrm{~cm}^{3}$ aliquots were suspended in Erlenmeyer flasks containing $50 \mathrm{ml}$ of anoxic artificial seawater ('Tropic Marin', $\mathrm{S}=15 \%$ ). These suspensions were sonicated 4 times for $10 \mathrm{~s}$ at $50 \mathrm{~W}$ (field samples) or magnetically stirred for 1 h (laboratory experiments). Serial dilutions $(10$-fold $)$ were prepared in screw-capped tubes $(150 \times 16 \mathrm{~mm})$ with rubber-coated aluminum caps containing brackish water enrichment medium No. 2 (Widdel 1980).

This enrichment medium was reduced with either $50 \mathrm{mM}$ of sodium dithionite (crystals) for field samples or $3 \mathrm{mM}$ of sodium disulfide for laboratory experiments. The medium contained the following vitamins $\left(\mu \mathrm{g}^{-1}\right)$ : biotin 10 , nicotinic acid 20, thiamine 10 , p-aminobenzoic acid 10, pantothenic acid 5, pyridox- amine 50, cobalamine 5 (Laanbroek \& Pfennig 1981, modified) and was gassed with $\mathrm{N}_{2} / \mathrm{CO}_{2}$ (90:10). Organic substrates serving as sole carbon sources and electron donors were added from sterile-filtered solutions at the following final concentrations: $15 \mathrm{mM}$ sodium acetate, $7.5 \mathrm{mM}$ sodium lactate, and $5 \mathrm{mM}$ disodium succinate. To enrich spore-forming SRB, the samples were pasteurized and incubated with $10 \mathrm{mM}$ of ethanol. Resazurin $(1 \mu \mathrm{m})$ served as redox indicator.

MPN determinations comprized 5 dilution steps with 5 parallels each. The tubes were incubated for $8 \mathrm{wk}$ at $20^{\circ} \mathrm{C}$ in the dark. Turbidity and hydrogen sulfide concentrations (Cord-Ruwisch 1985) were checked at 2 wk intervals.

\section{RESULTS}

\section{Distribution patterns}

From March to December 1989, MPNs of SRB obtained with acetate, succinate and lactate as electron donors ranged between $4 \times 10^{2}$ and $7 \times 10^{4}$ per $\mathrm{cm}^{3}$ of sediment. These viable counts roughly matched primary production rates in the water column, allowing a time lag of 2 to $3 \mathrm{wk}$ (Fig. 1). Decreasing redox potentials in the sediments coincided with increasing densities of SRB. However, even under the most oxidized conditions $(+280 \mathrm{mV})$, population densities as high as $2.9 \times 10^{4} \mathrm{~cm}^{-3}$ were obtained (Fig. 1). Further-
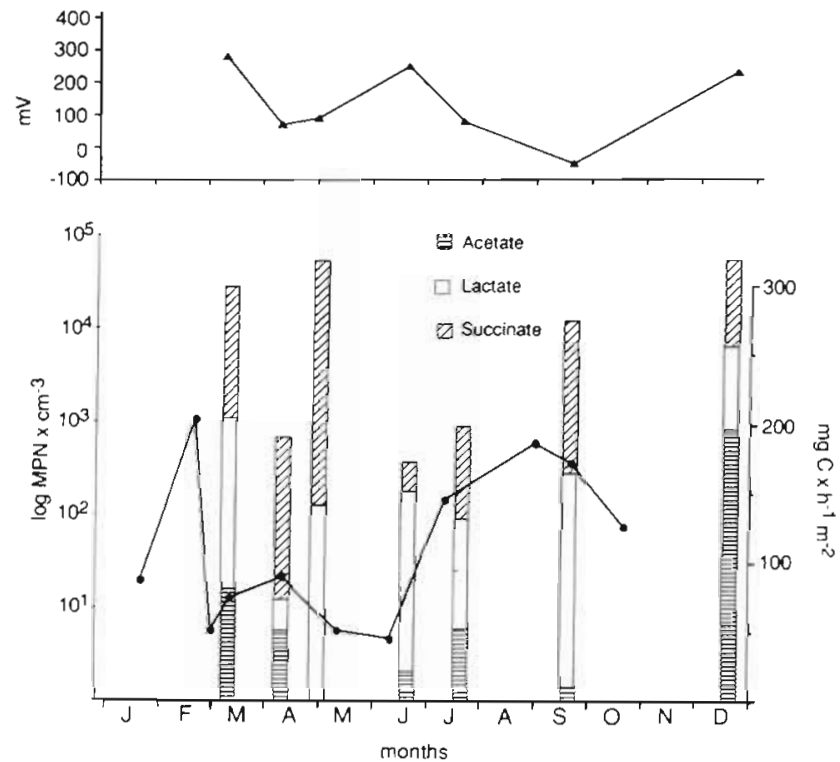

Fig. 1. Top: Fluctuations of redox potential (mV) at $5 \mathrm{~cm}$ sediment depth at Kiel Bay sampling station in 1989. Bottom: Seasonal changes of primary production $(\bullet)$ in the water column and MPNs of SRB in sediment obtained with acetate, lactate and succinate as carbon sources in 1989 


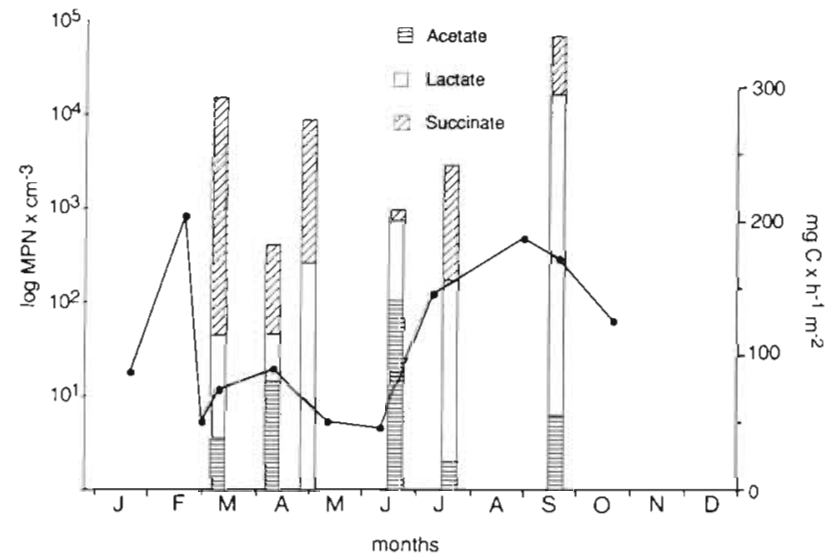

Fig. 2. Seasonal changes of primary production $(\bullet)$ in water column above sampling station (18 $\mathrm{m}$ water depth) and MPNs of epizoic SRB on Arctica islandica obtained with acetate, lactate and succinate as carbon sources in 1989

more, no overriding impact of temperature (ranging between 4 and $15^{\circ} \mathrm{C}$ ) on viable counts of SRB was detected.

Viable counts of epizoic SRB on shells of Arctica islandica (Fig. 2) were insignificantly higher than those in the ambient sediment (Fig. 1). In the latter, the percentage of lactate-, acetate- and succinate-oxidizing SRB fluctuated widely from 11 to $85 \%,<0.1$ to $26 \%$ and 10 to $62 \%$, respectively. In epizoic samples, the relative incidence of acetate-oxidizing SRB $(0.1$ to $67 \%$ ) tended to be greater than in the ambient sediment $(<0.1$ to $26 \%$ ) (Table 1 ).

\section{Laboratory experiments}

In jar experiments carried out to induce anaerobic survival of the clams, no significant differences between epizoic SRB and SRB in ambient sediment were found. However, the kinetics of enrichment in the MPN tubes revealed differences between epizoic SRB and SRB from the ambient sediment. To describe these enrichment characteristics, a value $\left(t_{\mathrm{MPN} / 2}\right)$ was defined as the time (in days) to reach $50 \%$ of the final MPN value obtained after $8 \mathrm{wk}$. Enrichment was slower in the ambient sediment samples than in the epizoic
Table 1 Relative abundance of SRB (\%) with respect to different electron donors (carbon sources) and tentative classification of the predominant taxa of SRB

\begin{tabular}{|c|c|c|c|}
\hline $\begin{array}{l}\text { Electron } \\
\text { donor }\end{array}$ & $\begin{array}{l}\text { Predominating } \\
\text { genera }\end{array}$ & Sediment & $\begin{array}{l}\text { Perio- } \\
\text { stracum }\end{array}$ \\
\hline Lactate & Desulfovibrio & $11.0-85$ & $20.0-71$ \\
\hline Acetate & $\begin{array}{l}\text { Desulfobacter and } \\
\text { Desulfotomaculum }\end{array}$ & $<0.1-27$ & $<0.1-67$ \\
\hline Succinate & $\begin{array}{l}\text { Desulfobacterium } \\
\text { and Desulfococcus }\end{array}$ & $10.0-62$ & $4.0-61$ \\
\hline Ethanol & Desulfotomaculum & $<0.1-3$ & $<0.1-1$ \\
\hline
\end{tabular}

samples. In epizoic samples, $t_{\mathrm{MPN} / 2}$ values of succinateutilizing SRB were only half as high as in samples from the ambient sediment (Table 2)

In a second experiment, overall differences of paired $t_{\mathrm{MPN} / 2}$ values for ambient sediment SRB and epizoic SRB indicated that succinate-utilizing epizoic SRB responded significantly more quickly $(\mathrm{p}=0.05, \mathrm{n}=6)$ (Fig. 3).

Succinate concentrations in the pore water of sediment with Arctica islandica were below the detection limit of $4 \mu \mathrm{mol} \mathrm{I}^{-1}$. This contrasted to the higher concentrations measured in the surrounding sediment.

\section{DISCUSSION}

The assessment of bacterial densities in sediments suffers from difficulties in separating and identifying individual cells. In addition, indirect techniques based on cultural enrichment, such as the determination of 'most probable numbers' (MPN), are affected by the selectivity of the growth conditions chosen and by the physiological state of the cells in situ. Even recovery of cultured SRB added to previously sterilized sediment is only about $50 \%$ (Gibson et al. 1987). Comparisons with measurements of sulfate reduction in situ and yield data obtained with cultured SRB have indicated that the standing crop of viable $\mathrm{SRB}$ in marine sedi-

Table 2. Final MPN values (after $8 \mathrm{wk}$ ), and $t_{\mathrm{MPN} / 2}$ values describing the velocity of enrichment of SRB using different electron donors in sediment tubes with Arctica islandica after $14 \mathrm{~d}$ of anaerobic survival. $\mathrm{n}=3$, standard error of the mean $\mathrm{SE}=\mathrm{s} \sqrt{\mathrm{n}}$

\begin{tabular}{lccrc|}
\hline Sole carbon source & \multicolumn{2}{c}{ Ambient sediment } & \multicolumn{2}{c|}{ Periostracum } \\
& $\mathrm{MPN} \times 10^{4} \mathrm{~cm}^{-3} \pm \mathrm{SE}$ & $t_{\mathrm{MPN} / 2}(\mathrm{~d}) \pm \mathrm{SE}$ & $\mathrm{MPN} \times 10^{4} \mathrm{~cm}^{-3} \pm \mathrm{SE}$ & $t_{\mathrm{MPN} / 2}(\mathrm{~d}) \pm \mathrm{SE}$ \\
\hline Acetate & $0.6 \pm 0.2$ & $29 \pm 8.6$ & $1.1 \pm 0.4$ & $38 \pm 6.9$ \\
Lactate & $5.7 \pm 0.7$ & $11 \pm 1.2$ & $11.1 \pm 8.7$ & $12 \pm 1.7$ \\
Succinate & $7.2 \pm 3.1$ & $33 \pm 8.6$ & $4.2 \pm 1.6$ & $18 \pm 2.3$ \\
\hline
\end{tabular}



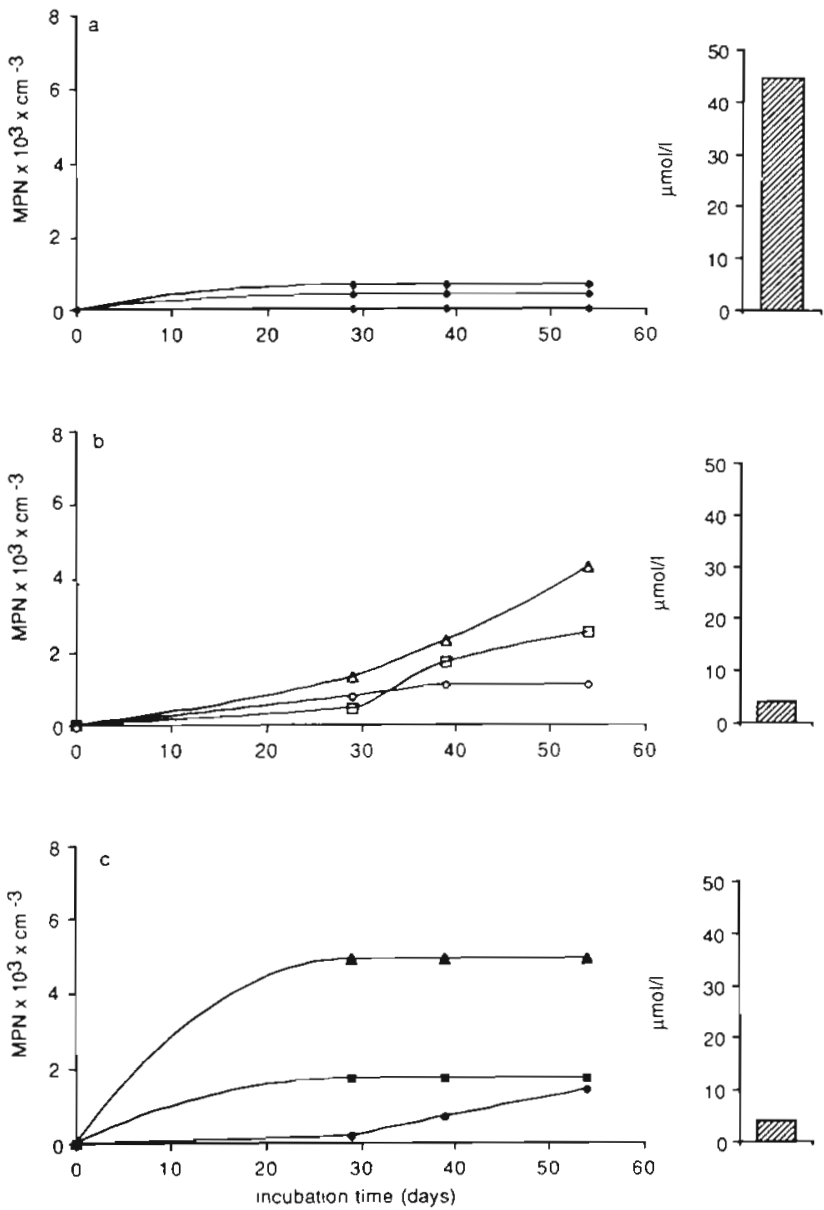

Fig. 3. Impact of anaerobic conditions ( 5 d) on development of MPN of SRB using succinate as sole carbon source in (a) the clam-free sediment (sieved), (b) sediment (sieved) surrounding Arctica islandica, and (c) samples from periostracum of $A$. islandica. Columns show succinate concentrations in the pore water

ments can be underestimated by a factor of 20 (Gibson et al. 1987). Other calculations have led to 1000-fold underestimates (Jørgensen 1978). Alternative techniques based on immunofluorescence do not appear promising due to their pronounced specificity below the level of taxonomic or physiological categories (Widdel 1988). Another alternative, phospholipid fatty acid biomarker analysis (e.g. Taylor \& Parkes 1985), depends on often extremely low percentages of fatty acids qualifying as specific biomarkers and has still to prove its superiority over conventional viable count estimates.

The spectrum of SRB as a target for estimates of viable counts has been considerably widened by the detection of new taxa and physiological groups (Pfennig et al. 1981). Our choice of lactate, acetate, and succinate (plus ethanol for spore formers) as single electron donors enabled us to distinguish between the major categories to be expected (Laanbroek \& Pfennig 1981, Widdel 1988). Also, if lactate in selective media is replaced by alternate electron donors, maximum abundances are still noted for lactate utilizers (Laanbroek \& Pfennig 1981, Battersby et al. 1985). Presumably, many of the Desulfovibrio spp. enriched on lactate medium (Table 1) are effective $\mathrm{H}_{2}$ scavengers in situ (Abram \& Nedwell 1978, Widdel 1988).

From activity measurements Banat et al. (1981) drew the conclusion that acetate- and $\mathrm{H}_{2}$-oxidizers coexist as 2 distinct functional groups in marine sediments. The great variations noted for acetate utilizers may be caused by frequent underestimates as a result of clumping as reported by Widdel \& Pfennig (1981). Furthermore, these counts may account for only a fraction of acetate oxidation, if, by means of interspecies hydrogen transfer (Phelps et al. 1985), even $\mathrm{H}_{2}$ utilizing Desulfovibrio spp. were able to participate in acetate oxidation (Widdel 1988).

It remains open to what extent the succinate utilizers, as an important group in this investigation. contained, beside complete oxidizers, also Desulfovibrio spp. (Postgate 1984). The consistently low percentage of spore formers (Desulfotomaculum spp.) occurring in the partly oxidized environment (Table 1) may indicate that oxygen tolerance of the spores is not the key for competitive advantage under unstable redox conditions.

Survival and activity of SRB in oxidized marine sediments have been explained by anoxic microniches and trapping of oxygen by the end product of sulfate reduction (Jørgensen 1977, Laanbroek \& Pfennig 1981. Battersby 1985). Furthermore, Desulfovibrio spp. and Desulfobacter postgatei show $\mathrm{O}_{2}$-dependent growth in oxygen-sulfide gradients in which primarily thiosulfate as an autoxidation product of sulfide has been suggested to replace sulfate as electron acceptor (Cypionka et al. 1985). Desulfovibrio vulgaris can survive exposure to oxygen for more than $72 \mathrm{~h}$ (Hardy \& Hamilton 1981).

An upward trend of viable counts between summer and fall concided with both decreasing redox potentials in the sectiment and, with a phase lag, increasing primary productivity in the water column. Enhanced $\mathrm{O}_{2}$ consumption and decreasing redox potentials in Kiel Bay sediment are characteristic of benthic responses to sedimentation of phytoplankton blooms (e.g Graf et al. 1982). Positive correlations between sedimentation rates and rates of sulfate reduction have already been found in other study areas (Goldhaber \& Kaplan 1975, Jørgensen 1982). Our data from Kiel Bay indicate that the standing crop of the obligately anaerobic SRB already increases before negative values of the redox potential are measured. 
Irrespective of gross underestimates of true population densities, linear relationships between sulfate reduction rates and SRB occur (Hines \& Lyons 1982). Uncoupling of these parameters, however, has been observed in macrofauna-rich sediments in which sulfate reduction rates were enhanced as a result of bioturbation by bivalves and other macro-infauna (Hines \& Jones 1985).

Growth of SRB is promoted by fermentation products such as low molecular weight fatty acids and $\mathrm{H}_{2}$. In oxidized sediments, fermentation is confined to microhabitats with a low redox potential. Such microhabitats occur in the intestinal tracts of marine animals (e.g. Plante et al. 1989). Moreover, under conditions of anaerobic survival, benthic infauna itself is capable of providing certain fermentation products for bacterial growth (Dion 1986, Oeschger 1990).

Manifestations of macroscopic bacterial growth as on Yoldia sp. from Antarctic mud samples (Bussmann \& Reichardt 1990) may be rare. An apparently similar phenomenon was recently described for a deep-sea mussel (Hook \& Golubic 1990). In general, however, bacterial utilization of nutrients released from clams is less spectacular. MPNs of SRB do not even indicate significantly higher densities on the periostracum of Arctica islandica. Only qualitative differences related to the velocity of enrichment would suggest a potential influence of the bivalve. Yet underestimates of MPN in samples from the shell surfaces cannot be excluded, because elevated concentrations of $\mathrm{Ca}$, when carried over into the enrichment medium, may cause sulfatereducing bacteria to form aggregates (Singleton et al. 1988).

Parameters describing the enrichment kinetics ( $t_{\mathrm{MPN} / 2}$ values) support the view that SRB occur in 2 groups with presumably different substrate affinities (Fukui \& Fukuhara 1987). By comparing $k_{\mathrm{M}}$ values for $\mathrm{SO}_{4}{ }^{2-}$ uptake by Desulfovibrio spp., Ingvorsen \& Jørgensen (1984) arrived at the same conclusion. Analogues of $t_{\mathrm{MPN} / 2}$ values determined for plate counts of cultured lactate-utilizing SRB seem to discriminate between different physiological states of these bacteria (Fukui \& Takii 1989a). Prolonged periods of starvation cause steadily declining respiratory activities and slowed-down 'rates of appearance of colonies (f)' (Fukui \& Takii 1989b).

Since $t_{M P N / 2}$ values were a factor of 2 lower for epizoic compared to ambient sediment succinateutilizing SRB, succinate availability on the clams ought to be higher than in the surrounding sediment. Since no succinate is detected in the presence of the clam, it appears possible that the turnover of this substrate is strongly enhanced by bacterial populations which have been activated or introduced by the clam. Under anoxic conditions, Arctica islandica and other bivalves produce acetate, propionate and succinate, though release of the latter into culture media has still to be verified (Kluytmans et al. 1975. Oeschger 1990). At any rate, as major accumulators of organic compounds and potent bioturbators in coastal sediments, bivalves are likely to exert a positive influence on bacterial. sulfate reduction (Hines et al. 1982, Hines \& Jones 1985. Oenema 1990)

Acknowledgements. Data on primary production in Kiel Bay were kindly provided by Dr U. Horstmann, Kiel.

\section{LITERATURE CITED}

Abram, J. W., Nedwell, D. B. (1978). Hydrogen as a substrate for methanogenesis and sulphate reduction in anaerobic saltmarsh sediment. Arch. Microbiol. 117: 93-97

Banat, I. M., Lindstrom, E. B., Nedwell, D. B., Balba, M. (1981). Evidence for coexistence of two distinct functional groups of sulfate-reducing bacteria in salt marsh sediment. Appl environ. Microbiol. 42: 985-992

Battersby, N. S., Malcolm, S. J., Brown, C. M., Stanley, S. O. (1985). Sulphate reduction in oxic and suboxic North-East Atlantic sediments. FEMS Microbiol. Ecol. 32: 225-228

Bussmann, I., Reichardt, W. (1990). Bacteria associated with marine bivalves during survival under anoxic conditions, Lesel, R. (ed.) Microbiology in poecilotherms. Elsevier Science Publ., Amsterdam, p. 163-167

Cord-Ruwisch, R. (1985). A quick method for the determination of dissolved and precipitated sulfides in cultures of sulfate-reducing bacteria. J. microbiol. Meth. 4: 33-36

Crill, P. M., Martens, C. S. (1987). Biogeochemical cycling in an organic rich coastal marine basin. 6. Temporal and spatial variations in sulfate reduction rates. Geochim. Cosmochim. Acta 51. 1175-1186

Cypionka, H., Widdel, F., Pfennig, N (1985). Survival of sulfate-reducing bacteria after oxygen stress, and growth in sulfate-free oxygen-sulfide gradients. FEMS Microbiol. Ecol. 31: $39-45$

Dion, P. (1986). Utilization of octopine by marine bacteria isolated from molluscs. Can. J. Microbiol. 32: 959-963

Fukui, M., Fukuhara, H. (1987). Colony formation on agar plates by sulfate-reducing bacteria in water and sediment of lakes. Bull. Jap. Soc. Microbiol. Ecol. 1: 75-78

Fukui, M., Takii, S. (1989a). Kinetics of colony formation by sulfate-reducing bacteria. Bull. Jap. Soc. Microbiol. Ecol. 3: $67-71$

Fukui, M., Takii, S. (1989b). Reduction of tetrazolium salts by sulfate-reducing bacteria. FEMS Microbiol. Ecol. 62: $13-20$

Gibson, G. R., Parkes, R. J., Herbert, R. A. (1987). Evaluation of viable counting procedures for the enumeration of sulfate-reducing bacteria in estuarine sediments. J. microbiol. Meth. 7. 201-210

Goldhaber, M. B., Kaplan, I. R. (1975). Controls and consequences of sulfate reduction in recent marine sediments. Soil Sci. 119: 42-55

Graf, G., Bengtson, W., Diesner, U., Schulz, R., Theede, H (1982). Benthic response to sedimentation of a spring phytoplankton bloom: process and budget. Mar. Biol. 67 : 201-208

Gunnarsson, L. A. H., Rönnow, P. H. (1982). Interrelationships between sulfate-reducing and methane-producing bac- 
teria in coastal sediments with intense sulfide production. Mar. Biol. 69: 121-128

Hardy, J. A., Hamilton, W. A. (1981). The oxygen tolerance of sulfate-reducing bacteria isolated from North Sea waters. Curr. Microbiol. 6: 259-262

Henrichs, S. M, Reeburgh, W. S. (1987). Anaerobic mineralization of marine sediment organic matter: rates and the role of anaerobic processes in the oceanic carbon economy. Geomicrobiol. J. 5: 191-237

Hines, M. E., Buck, J. D. (1982). Distribution of methanogenic and sulfate-reducing bacteria in near-shore marine sediments. Appl. environ. Microbiol. 43: 447-453

Hines, M. E., Jones, G. E. (1985). Microbial biogeochemistry and bioturbation in the sediments of Great Bay, New Hampshire. Estuar. coast. Shelf Sci. 20: 729-742

Hines, M. E., Lyons, W. B. (1982). Biogeochemistry of nearshore Bermuda sediments. 1. Sulfate reduction rates and nutrient generation. Mar. Ecol. Prog. Ser. 8: 87-94

Hines, M. E., Orem, W. H., Lyons, W. B., Jones, G. E. (1982). Microbial activity and bioturbation-induced oscillations in pore water chemistry of estuarine sediments in spring. Nature, Lond. 299: 433-435

Hook, J E., Golubic, S. (1990). Mussel periostracum from deep-sea redox communities as a microbial habitat: 2 . The pit borers. P.S.Z.N. I: Mar. Ecol. 11: 239-254

Ingvorsen, K., Jargensen, B. B. (1984). Kinelic of sulfate uptake by freshwater and marine species of Desulfovibrio. Arch. Microb. 139: 61-66

Jørgensen, B. B. (1977). Bacterial sulfate reduction within reduced microniches of oxidized marine sediments. Mar. Biol. 41:7-17

Jørgensen, B. B. (1978). A comparison of methods for the quantification of bacterial sulfate reduction in coastal marine sediments III. Estimation from chemical and bacteriological field data. Geomicrobiol. J. 1: 11-64

Jørgensen, B. B. (1982). Mineralization of organic matter in the sea bed: the role of sulfate reduction. Nature, Lond. 296: $643-645$

Jørgensen, B. B., Sorensen, J. (1985). Seasonal cycles of $O_{2}$, $\mathrm{NO}_{3}{ }^{2-}$ and $\mathrm{SO}_{4}{ }^{2-}$ reduction in estuarine sediments: the significance of an $\mathrm{NO}_{3}^{-}$reduction maximum in spring. Mar. Ecol. Prog. Ser. 24:65-74

Kluytmans, J. H., Veenhof, P. R., Zwaan, A. D. (1975). Anaerobic production of volatile fatty acids in the sea mussel Mytilus edulis L. J. comp. Physiol. 104: 71-78

Laanbroek, H. J., Pfennig, N. (1981). Oxidation of short-chain fatty acids by sulfate-reducing bacteria in freshwater and

This article was submitted to the editor in marine sediments. Arch. Microbiol. 128: 330-335

Michal, G., Beutler, H.-O., Lang, G., Günther, U. (1976). Enzymatic determination of succinic acid in foodstuffs. $Z$. analyt. Chem. 279: 137-138

Oenema, O. (1990). Sulfate reduction in fine-grained sediments in the Eastern Scheldt, southwest Netherlands. Biogeochemistry 9: $53-74$

Oeschger, R. (1990). Long-term anaerobiosis in sublittoral marine invertebrates from the Western Baltic Sea: Halicryptus spinulosus (Priapulida), Astarte borealis and Arctica islandica (Bivalvia). Mar. Ecol. Prog. Ser. 59 $133-143$

Pfennig, N., Widdel, F., Trüper, H. G. (1981). The dissimilatory sulfate-reducing bacteria. In: Starr, M. P., Stolp, H., Trüper, H. G., Balows, A., Schlegel, H. G. (eds.) The prokaryotes, 1. Springer Verlag, Berlin, p. 926-940

Phelps, I J., Conrad, R., Zeikus, J. G. (1985). Sulfatedependent interspecies $\mathrm{H}_{2}$ transfer between Methanosarcina barkeri and Desulfovibrio vulgaris during coculture metabolism of acetate or methanol. Appl. environ. Microbiol 50: 589-594

Plante, C. J., Jumars, P. A., Baross, J. A. (1989). Rapid bacterial growth in the hindgut of a marine deposit feeder Microb. Ecol. 18: 29-44

Postgate, J. R. (1984). Genus Desulfovibrio. In: Krieg, N. R., Holt, J. G. (ed.) Bergey's manual of systematic bacteriology, 1. Williams \& Wilkins, Baltimore, p. 666-672

Singleton, R., Ketcham, R. B., Campbell, L. L. (1988). Effect of calcium cation on plating efficiency of the sulfatereducing bacterium Desulfovibrio vulgaris. Appl environ. Microbiol. 54: 2318-2319

Taylor, J., Parkes, R. J. (1985). Identifying populations of sulphate-reducing bacteria within marine sediment systems, using fatty acid biomarkers. J. gen. Microbiol. 131: $631-642$

Widdel, F. (1980). Anaerober Abbau von Fettsäuren und Benzoesäure durch neu isolierte Arten Sulfat-reduzierender Bakterien. Ph.D. thesis, University of Gottingen

Widdel, F (1988). Microbiology and ecology of sulfate- and sulfur-reducing bacteria. In: Zehnder, A. J. (ed.) Biology of anaerobic microorganisms. J. Wiley, New York, p. 469-585

Widdel, F., Pfennig. N. (1981). Studies on dissimilatory sulfate-reducing bacteria that decompose fatty acids I. Isolation of new sulfate-reducing bacteria with acetate from saline environments. Description of Desulfobacter postgateigen. nov., sp. nov. Arch. Microbiol. 129: 395-400

Manuscript first recelved: March 7, 1991

Revised version accepted: October 24, 1991 